\title{
Students' opinions on the need for interactive multimedia development for entrepreneurship learning
}

\author{
Mochamad Kamil Budiarto, Triana Rejekiningsih, Sudiyanto Sudiyanto \\ Department of Educational Technology, Sebelas Maret University, Indonesia
}

\begin{tabular}{l} 
Article Info \\
\hline Article history: \\
Received Dec 28, 2020 \\
Revised Aug 24, 2021 \\
Accepted Sep 7, 2021 \\
\hline Keywords: \\
ICT assisted learning \\
Multimedia interactive \\
Opportunities \\
Students' opinion
\end{tabular}

\begin{abstract}
The use of information technology in education has the potential to have positive outcomes in the face of globalization. This study aimed to identify various needs in order to integrate technology into learning. The study employed a quantitative approach with a survey method to senior high schools. The questionnaire was used as a data collection instrument which was distributed to a research sample of 60 students who were randomly selected. The results revealed that students' attitudes toward the integration of technology into the learning process are inversely proportional to their use of learning media, which is still limited to the printed module. Students would like to create interactive multimedia as a medium for learning craftsmanship and entrepreneurship, based on the needs of students who are technologically literate and efforts to optimize the use of facilities that available at school.
\end{abstract}

This is an open access article under the CC BY-SA license.

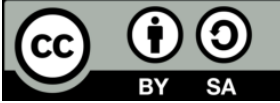

\section{Corresponding Author:}

Triana Rejekiningsih

Department of Educational Technology, Faculty of Teacher Training and Education

Sebelas Maret University

Ir. Sutami Street no. 36 Kentingan, Surakarta, Central Java, 57126, Indonesia

Email: triana_rizq@staff.uns.ac.id

\section{INTRODUCTION}

In facing the developments in the era of the industrial revolution 4.0, various competencies are required. The readiness of human resources (HR) plays an important role in building a civilization. They must be prepared from an early age with competencies relevant to the needs of the 21 st century [1]. In the context of macro education, the adjustment and update of the national education system to the needs of the world continue with the hope that the education system can provide maximum facilities for the implementation of learning activities.

Teaching and learning activity or learning process is the implementation of the national curriculum to each level of education to enable the students to master certain skills and abilities predetermined in the learning objectives [2]. Rusman [3] added that learning is a process of improvement by providing material and assignments to solve problems formed in an interaction between the teacher and his students. Learning is a condition in which individuals experience thinking events and process information to develop the knowledge they want to acquire [4]. The best learning process occurs when the teacher's role is not too dominating because, when the learning process is dominated by the teacher, the students will be more likely to be passive [5]. Many factors affect student success during learning [5], [6], including student internal factors, learning environment, teacher competence [7], the difficulty level of the subject matter, and the availability of supporting facilities for the learning process [8].

In case of the development and advancement of technology, the education system is required to adjust the competencies to be mastered by students, resulting in changes to the implementation of the national curriculum. This is as revealed by Sofyan [9] that the ideal concepts for the Indonesian 2013 
curriculum process standard include the use of student-centered learning, contextual learning, textbooks that contain material, and effective and efficient learning process, supported by a comprehensive assessment system and relevant competencies to compete amid the industrial revolution 4.0. In line with the innovation of the learning process in the 21 st century is the use of electronic-based learning media or information and communication technology (ICT) in education [10], [11]. This has resulted in various educational institutions around the world making major changes to adjust with the curriculum to meet the demands for the skills and abilities needed in the current era [12]. One way face the challenge is to integrate technology into the classroom and make teachers innovative learning facilitators [11], [13], [14].

The use of ICT packaged in a computer is an innovation that can be applied in learning [15]-[17]. As part of forms of technology computer has a great potential for learning processes because the development of technology has become an integral part of human life, moreover computer has been considered as one of the appropriate digital devices for the educational process [18], [19]. This is similar to the study conducted by Shatri [20] regarding the implementation of the ICTs in education institutions in several countries such as Thailand, Myanmar and Singapore, the study results indicate the fact that the integration of the ICTs into the education system is a basis of the formation of higher human resources, this shows that Singapore, Thailand, Indonesia, and Myanmar have demonstrated an initiative to integrate ICT into education. Singapore has successfully implemented ICT in all sectors in its education implementation plans, whereas Thailand, Indonesia, and Myanmar include ICT as one of the mentioned aspects in the Central Government Master Plan. Another research conducted by Erdoğan and Dede [21] revealed that ICT offers considerable benefits for students. A study conducted at the junior secondary education level in Turkey found that nearly $80 \%$ of respondents stated that ICT provides numerous benefits, such as making it easier for students to obtain material and lesson information. Referring to some of these studies, the integration of ICT in implementing education is an important part to consider because of the many benefits it offers. As a result, this study focuses on the issue of identifying the use of ICT as a form of the need analysis in attempt to develop an innovative learning media integrated with ICT for subjects taught in schools, namely the craft and entrepreneurship subjects.

In addition to facilitating the learning process for conveying information in the form of material, learning media can also raise student interest in learning [22], [23]. The use of technology is expected to improve the quality of teachers, leading to a quality learning process. ICT systems provide an unlimited distribution of information to be more effective and efficient [18], [21]. Various forms of technology use in the learning process include game-based learning [24], web-based learning [25], [26], computer-assisted learning [27]-[29], and audio-visual-based learning [30]. Thus, the use of ICT-integrated media in learning can help students develop their skills, increase their motivation, and expand their knowledge independently in accordance with their learning styles [31], [32]. Interactive multimedia is one alternative media that is integrated with ICT. This media can be operated through computers [33]. The components of interactive multimedia are text, image, video, animation, and other elements of interactivity to can engage and influence the students during the learning process [34]. On the other hand, learning multimedia is considered capable of creating a more active and informed learning environment and can be used as a reference for learning activities other than the teacher [35].

In line with the use of ICT in the learning process, entrepreneurship is a competency needed for individuals amid this global competition [36]. Entrepreneurship education in general is a dynamic educational and social process because it can shape individual life skills through an integrated curriculum in schools [37]. As in Mexico, which believes that education has a significant impact on economic activity and that the state must be able to mitigate the negative impact of technological development through entrepreneurship education, there is a great deal of hope that entrepreneurship education can increase human resource competence to become entrepreneurs and create jobs [38]. Entrepreneurship is a skill that can be learned by anyone [39], so it is not a new thing that entrepreneurship is the main subject in the Indonesian 2013 curriculum implemented in Indonesia to change and develop students' mindset [40]. Craftsmanship and entrepreneurship are the subjects of senior high school students as contained in the Indonesian 2013 curriculum. The material in this subject aims to foster students' enthusiasm and entrepreneurship since at school to create young entrepreneurs in Indonesia, given the importance of entrepreneurship to be mastered by students to face challenges according to the needs of the industrial revolution 4.0 [41]. This subject is also to cultivate an entrepreneurial spirit through the mastery of practical concepts regarding crafts, engineering, cultivation, and processing [42].

The ICT in the form of interactive multimedia programs and the composition of the material has been integrated with the environment as an innovative approach to implement learning which is considered capable of solving problems that occur during the learning process. Based on the findings of a preliminary study involving four meetings of observations of the learning process, it shows that the teacher has not yet refined the use of instructional media, only relied on the print module as a learning media.

Students' opinions on the need for interactive multimedia development for ... (Mochamad Kamil Budiarto) 
Furthermore, semi-structured interviews with subject teachers revealed that up to this point, teachers have only used print modules provided by the government and have never used technology such as interactive multimedia for classroom learning, indicating that the importance of information technology in learning has not been realized. As a consequence, educators should innovate in the use of media for craft learning and entrepreneurship as one of the subjects whose mastery is critical for students. This is in line with the content of the 2013 curriculum that concerns more about the implementation of the craftsmanship and entrepreneurship subject where teachers are encouraged to use local potentials as learning materials [43]. It is expected that the use of learning multimedia with the local potential material can better facilitate students in the classroom learning process [44]. This research aims to obtain information about the use of media during learning, perceptions and opportunities for developing and using multimedia as a learning media for entrepreneurship learning in high school, and school supporting facilities. It is hoped that this research can produce information as a form of needs analysis to develop the product of multimedia model for craftsmanship and entrepreneurship learning.

\section{RESEARCH METHOD}

In this descriptive research, quantitative approach with survey method was employed [45]. The survey involved the eleventh-grade students at Senior High School in Cirebon, Indonesia as the population in this study. The sample in this study was 60 eleventh grade students who selected randomly.

The research instrument used was a questionnaire which was developed based on the points of needs analysis from the implementation of the research [16], [46]. The data were collected using a questionnaire in the form of statements and questions that refer to a Likert scale of one to five (1-5) with specific details such as: 1 (Strongly Disagree/SD), 2 (Disagree/D), 3 (Neutral/N), 4 (Agree/A), and 5 (Strongly Agree/SA). The data collection instrument was a questionnaire with ten questions that were assessed by an expert, a lecturer with a background in educational technology science.

The procedure for conducting this study began with the distribution of the needs analysis questionnaire that had been assessed by the expert to the research sample, which consisted of 60 high school students who were given the craft and entrepreneurship subjects. Following the completion of the classroom learning process, the questionnaire was distributed to students. Having followed the completion of the questionnaire, the results of the students' responses to the questionnaire distribution would be analyzed. The student's response will be analyzed descriptively and in percentage which is intended to determine the level of the highest percentage of answers to make it easier to identify the conditions, problems, which occurs during the learning process of craftsmanship and entrepreneurship, particularly the use of learning media, the availability of facilities and infrastructure, as well as student opinions on the implementation of interactive multimedia as ICT-based learning media [47].

\section{RESULTS AND DISCUSSION}

The needs analysis in this research sought information about the use of learning media, perceptions and opportunities for the use and development of multimedia in entrepreneurship learning, and school supporting facilities. As mentioned previously, the data were collected using a questionnaire with a Likert scale of one to five with the details of SD (Strongly Disagree), D (Disagree), N (Neutral), A (Agree), SA (Strongly Agree). The results of the study are divided into several sections, including identification of instructional media use, student perceptions of innovative multimedia-based learning media development, and support for school-owned facilities and infrastructure.

\subsection{The use of learning media by teachers}

This section will present the results obtained from student responses to the distribution of the questionnaire. The first aspect is related to the information on the use of media in craftsmanship and entrepreneurship learning. Regarding the student response to the use of learning media, most teachers use printed modules provided by the government. A total of $66.7 \%$ of students agree that, in the learning process, teachers often use modules provided by the government. The information regarding learning activities was also obtained. The teacher had used multimedia as a learning media, although not too often. The interviews revealed with the teacher revealed that the commonly-used multimedia was PowerPoint-based presentation media. From the next item of the questionnaire, the responses of students who agree and disagree are almost balanced even though most of them 'Agree' (53.3\%) that teachers have used learning multimedia. This refers to the previous point that teachers and students consider that PowerPoint shows that contain material and are delivered during the learning process represents the use of multimedia in learning. Overall related to this aspect, the student response results data are illustrated in Figure 1 and Figure 2. 


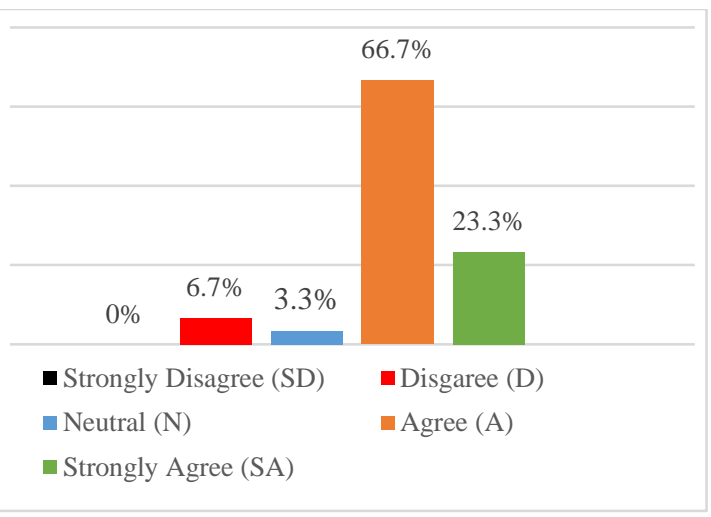

Figure 1. The use of module-based learning media

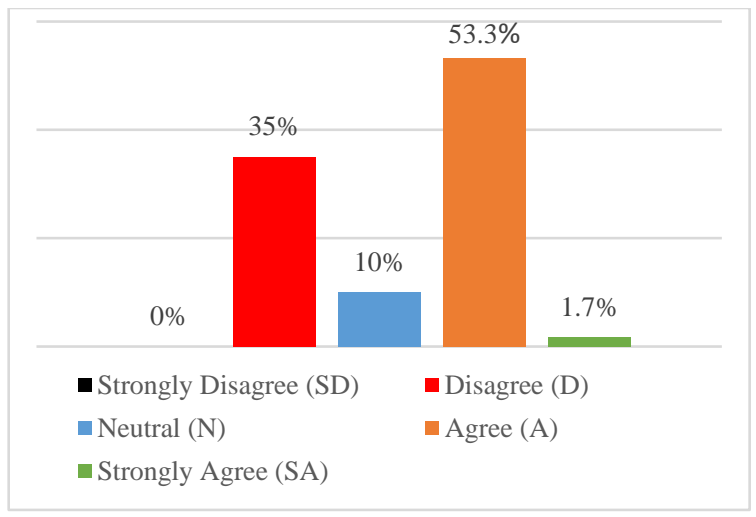

Figure 2. Student responses related to interactive multimedia that has never been used by the teacher

\subsection{Perceptions and opportunities of multimedia interactive as learning media}

This section describes the results of student responses to aspects of the perceptions and opportunities of multimedia as an alternative learning media for craftsmanship and entrepreneurship learning. The results of student responses are described in Table 1. Table 1 shows that the students agree to develop and use multimedia for craftsmanship and entrepreneurship learning as indicated by the acquisition of the highest scale of student responses where $60 \%$ of them answer 'Agree'. Supported by $33.3 \%$ of students who stated that they "Strongly Agree" if interactive multimedia is developed and used in craft learning and entrepreneurship. This shows if Multimedia has a big opportunity to be used as an innovation for the learning process considering that the students have had computer operating skills. Even though the table identifies that only $43.3 \%$ of students answered 'Neutral' or 'enough', some said that they had very proficient computer operating skills sequentially: 18.3\% 'Strongly Agree' while 30\% 'Agree'.

Table 1. Perceptions and opportunities of learning multimedia for entrepreneurship learning

\begin{tabular}{ccccccc}
\hline Item (Questionnaire) & \multicolumn{3}{c}{ Scale } & \multicolumn{2}{c}{ Highest percentage scale } \\
\hline Good computer operation ability & 0 & 5 & 26 & 18 & 11 & $43.3 \%$ (Neutral) \\
$\begin{array}{c}\text { Agree or disagree with the use of interactive } \\
\text { multimedia based on local potential in learning. }\end{array}$ & 0 & 1 & 3 & 36 & 20 & $60 \%$ (Agree) \\
\hline
\end{tabular}

\subsection{Supporting learning facilities in school}

Computer laboratories equipped with complete computer units are one important component in applying ICT in schools, both in the school management system and for the implementation of learning. The presence of ICT in the form of computers is expected to be integrated and utilized for the learning process, given the many positive impacts of using computers in the learning process in schools, Thus, the availability of learning support facilities, such as school-owned computers, is critical in determining needs in order to innovate the use of learning media.

The next student response pertains to the availability of school-owned supporting facilities. Supporting facilities, such as computers, are the next important aspect of needs analysis in the context of developing and implementing learning media using computers as described in the Figure 3. Figure 3 shows that the students' responses to supporting facilities in the learning process, especially those related to the application of ICT in teaching and learning activities, are high where 53.3\% of them 'Agree' that schools have computer laboratory that can be used for the learning process. Then there were $18.3 \%$ of students who answered 'Neutral,' and $13.3 \%$ of students who answered 'Disagree.' Then according student responses, schools have adequate facilities to implement information technology assisted learning, particularly the use of interactive multimedia. This is indicated by the $53.3 \%$ who responded "Agree" if the school already has computer laboratory facilities. 


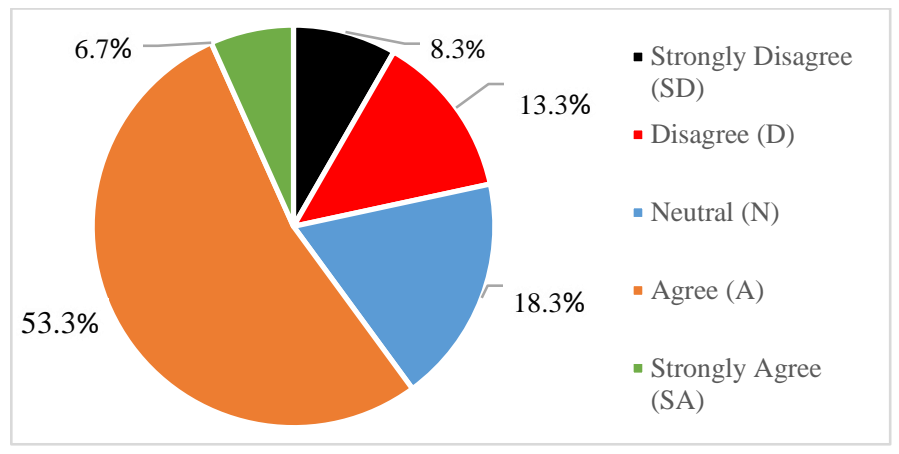

Figure 3. Student responses related to the availability of computer laboratories

\subsection{Discussion}

The national education system continues to adjust the competencies needed by the students to compete in technology so that learning that was previously teacher-centered slowly began to shift to studentcentered learning [48]. How teachers choose and apply strategies, methods, and media for the learning process will affect the achievement of competencies needed in the current 21st century [49]. Knowing the predetermined material, information, and standards for a learning process, students' prior knowledge, and choosing learning resources to meet their needs are important to do by a teacher [50]. The presence of multimedia interactive is initiated by the development of ICT which requires students to have 21 st-century skills, which was technology operating skill or other digital aspects such as technological literacy [51], [52]. Hence, the use of computers will be one solution for today's learning.

The material delivered through learning multimedia has several advantages when it is only delivered orally, given the interactive characteristics of multimedia in the sense that it gives freedom for students to choose the material to study [53] and accommodates information in the form of audio-visual, text, and image, based on the arrangement of the multimedia [54]. Many kinds of learning media products including multimedia, before being applied in the learning process, must be assessed by experts to ensure their quality and the quality of the material to reach the feasible level for use in the learning process. This corresponds to the previous research done by Kareem [55] that has developed a learning product, namely multimedia for social studies learning on the material of geographical conditions in Indonesia for elementary schools with the scores from media experts related to the validity of $87.92 \%$, practicality of $92.47 \%$, and attraction of 93.57\%. Based on these results, the multimedia learning product developed is considered feasible for use in the learning process.

On the other hand, the use of learning multimedia can affect student academic achievement [56], attract their attention, help them to master the concepts of the material presented, create an active learning atmosphere, and become a media for students to learn individually according to their cognitive abilities [57][59]. The research that the assessment score in science and technology of the experimental group was significantly higher than that of the control group, indicating that the computer-assisted learning process gives more advantages than learning using conventional media [22]. Other research suggests that the use of computerassisted multimedia plays a positive role in the mastery of English vocabulary [23]. The use of computers and software that can support the learning process could provide a better communication channel because the teaching material is presented more variedly so that students can receive it using visuals, audio, or both [60]. The use of modern learning media such as computers and other educational software will allow students to get information quickly, thereby increasing their learning interest and academic achievement [61], [62].

In line with several opinions and discussions about the usefulness of interactive multimedia as a type of learning media, interactive multimedia can effectively transmit messages found in the learning materials. Besides, multimedia is convergent in nature, which can contain information or material according to the needs, not for one particular subject [62]. Local potential value can be used as a component to be integrated with learning materials, especially for the craftsmanship and entrepreneurship subject as shown by the previous research [63], [64] that has successfully optimized local potential to improve the quality of learning. However, in the learning process, both in terms of preparation, implementation and evaluation, we cannot negate the figure of a teacher, considering teachers play an important role in educating their students in the era of the industrial revolution 4.0. In this era, entrepreneurship should not only be taught through conventional learning methods and media, but there also needs to be a form of learning innovation to help students have entrepreneurship as demanded in this era [11]. This learning innovation can help students to overcome learning difficulties and improve their outcomes. 
This research was carried out to identify a form of learning media that is integrated with technology in craftsmanship and entrepreneurship subject. Based on the results of the identification, opportunities, and discussion, other research is needed as a follow-up by identifying opportunities for implementing learning media in other formats to support the learning process. The findings of this research can be used as a basis for developing a local potential-based interactive multimedia model of entrepreneurship as an alternative instructional media. This is certainly inseparable from referring to the study results which show various types of school readiness in terms of support facilities such as the availability of computer laboratories, human resources where students have good abilities in operating computer devices, and the minimal variation in the use of learning media used by teachers. It has been explained about the results of previous studies that show the use of interactive multimedia has many positive effects for students, so this needs analysis study was indeed crucial for providing as a framework in developing an innovative learning media, namely interactive multimedia for classroom learning.

\section{CONCLUSION}

The study found that students' attitudes toward the integration of technology into the learning process are inversely proportional to their use of learning media, which is still limited to the printed module. Students would like to create interactive multimedia. It is as a medium for learning craftsmanship and entrepreneurship, based on the needs of students who are technologically literate and efforts to optimize the use of facilities such as computer labs available at school.

As part of an effort to improve the quality and quality of education in the twenty-first century, the presence of information technology in the learning process provides various types of convenience and benefits for students. The implementation of handcrafted learning and teacher entrepreneurship continues to rely on static learning media such as printed modules and is unable to take advantage of and optimize the availability of supporting facilities already available in schools, such as computer laboratories. The real strategy for improving learning quality is to integrate ICT into the learning process, considering that schools already have very supportive facilities, as well as to substitute print modules with interactive multimedia as learning media. This study has been limited to identifying problems in the use of ICT-based learning media with a population in one area. Therefore, future researchers can use the results of this study to develop instructional media products that are integrated with ICT, or they can increase the study focus on teacher data collection on ICT-based learning in schools, considering the benefits of ICT-based learning and technological support and success resources as a determining factor in achieving learning objectives.

\section{REFERENCES}

[1] L. V. Wihartanti and R. P. Wibawa, "Development of e-Learning Microsoft Sway as innovation of local culturebased learning media," Din. Pendidik., vol. 12, no. 1, pp. 53-60, 2017, doi: 10.15294/dp.v12i1.10582.

[2] N. Shamsuddin and J. Kaur, "Students' learning style and its effect on blended learning, does it matter?" International Journal of Evaluation and Research in Education (IJERE), vol. 9, no. 1, pp. 195-205, 2020, doi: 10.11591/ijere.v9i1.20422.

[3] Rusman, Learning models, (in Indonesia). Jakarta: PT Raja Grafindo Persada, 2013.

[4] R. I. Arends, Learning to Teach. Jakarta: Salemba Humanika, 2013.

[5] S. Sutarto, "Cognitive theory and its implications for learning," (in Indonesia), Islam. Couns. J. Bimbing. Konseling Islam, vol. 1, no. 2, pp. 1-26, 2017, doi: 10.29240/jbk.v1i2.331.

[6] B. Kurniawan, O. Wiharna, and T. Permana, "Study analysis of factors affecting learning outcomes in basic automotive electrical engineering subjects," (in Indonesia), J. Mech. Eng. Educ., vol. 4, no. 2, pp. 156-162, 2018, doi: 10.17509/jmee.v4i2.9627.

[7] Y. Adrian and R. L. Agustina, "Teacher competencies in the industrial revolution era 4," (in Indonesia), Lentera J. Pendidik., vol. 14, no. 2, pp. 175-181, 2019, doi: 10.33654/jpl.v14i2.907.

[8] N. I. Tukenova, G. A. Mursakimova, M. L. Gruzdeva, K. Z. Chetiyeva, A. U. Elepbergenova, and A. A. Iskakova, "Educational multimedia-resources in education," Int. J. Innov. Technol. Explor. Eng., vol. 8, no. 10, pp. 3617-3620, 2019, doi: 10.35940/ijitee.J9788.0881019.

[9] F. A. Sofyan, "The implementation of HOTS in curriculum 2013," (in Indonesia), Inventa, vol. 3, no. 1, pp. 1-9, Mar. 2019, doi: 10.36456/inventa.3.1.a1803.

[10] S. D. A. Bujang, A. Selamat, O. Krejcar, P. Maresova, and N. T. Nguyen, "Digital Learning Demand for Future Education 4.0-Case Studies at Malaysia Education Institutions," Informatics, vol. 7, no. 2, p. 13, 2020, doi: 10.3390/informatics7020013

[11] R. K. Dewi, S. Wardani, N. Wijayati, and W. Sumarni, "Demand of ICT-based chemistry learning media in the disruptive era," International Journal of Evaluation and Research in Education (IJERE), vol. 9, no. 2, pp. 265-270, 2019, doi: 10.11591/ijere.v8i2.17107. 
[12] T. O. Kowang, et al., "Industry 4.0 competencies among lecturers of higher learning institution in Malaysia," International Journal of Evaluation and Research in Education (IJERE), vol. 9, no. 2, pp. 303-310, 2020, doi: 10.11591/ijere.v9i2.20520.

[13] F. Mikre, "The roles of information communication technologies in education: Review article with emphasis to the computer and internet," Ethiop. J. Educ. Sci., vol. 6, no. 2, pp. 109-126, 2011.

[14] E. A. Makarova and E. L. Makarova, "Blending pedagogy and digital technology to transform educational environment," Int. J. Cogn. Res. Sci. Eng. Educ., vol. 6, no. 2, pp. 57-65, 2018, doi: 10.5937/ijcrsee1802057M.

[15] P. U. Osadebe and J. F. Osadebe, "Undergraduate business education students' perception on information and communication technology use in teaching and learning," International Journal of Evaluation and Research in Education (IJERE), vol. 9, no. 2, pp. 359-363, 2020, doi: 10.11591/ijere.v9i2.20326.

[16] L. Stošić, "Parents opinions of the impact of computers on the social behavior of children," Int. J. Cogn. Res. Sci. Eng. Educ., vol. 2, no. 1, pp. 57-61, 2014.

[17] S. H. Halili, "Technological advancements in education 4.0," Online J. Distance Educ. e-Learning, vol. 7, no. 1, pp. 63-69, 2019.

[18] H. Jeong, C. E. Hmelo-Silver, and K. Jo, "Ten years of Computer-Supported Collaborative Learning: A metaanalysis of CSCL in STEM education during 2005-2014," Educ. Res. Rev., vol. 28, Nov. 2019, doi: 10.1016/j.edurev.2019.100284.

[19] M. T. Machmud, A. P. Widiyan, and N. R. Ramadhani, "The development and policies of ICT supporting educational technology in Singapore, Thailand, Indonesia, and Myanmar," International Journal of Evaluation and Research in Education (IJERE), vol. 10, no. 1, pp. 78-85, 2021, doi: 10.11591/ijere.v10i1.20786.

[20] Z. G. Shatri, "Advantages and disadvantages of using information technology in learning process of students," $J$. Turkish Sci. Educ., vol. 17, no. 3, pp. 420-428, 2020, doi: 10.36681/tused.2020.36.

[21] Y. Erdoğan and D. Dede, "Computer assisted project-based instruction: The effects on science achievement, computer achievement and portfolio assessment," Int. J. Instr., vol. 8, no. 2, pp. 177-188, 2015.

[22] M. Han and S. Niu, "Effect of computer multimedia assisted word annotation on incidental vocabulary acquisition of English reading," Int. J. Emerg. Technol. Learn., vol. 14, no. 13, pp. 21-32, 2019, doi: 10.3991/ijet.v14i13.10705.

[23] G. Jin, S. Nakayama, and M. Tu, "Game based learning for safety and security education," Journal of Education and Learning (EduLearn), vol. 14, no. 1, pp. 114-122, 2020, doi: 10.11591/edulearn.v14i1.14139.

[24] Y. Zhang, "Development of WebGL-based Virtual Teaching Platform for Mold Design," Int. J. Emerg. Technol. Learn., vol. 13, no. 6, pp. 16-28, 2018, doi: 10.3991/ijet.v13i06.8581.

[25] M. E. Aksoy, F. Guven, M. E. Sayali, and D. Kitapcioglu, "The effect of web-based learning in pediatric basic life support (P-BLS) training," Comput. Human Behav., vol. 94, pp. 56-61, May 2019, doi: 10.1016/j.chb.2018.12.032.

[26] B. Raji, "Significance and challenges of computer assisted education programs in the UAE: A case study of higher learning and vocational education," Educ. Inf. Technol., vol. 24, no. 1, pp. 153-164, Jan. 2019.

[27] N. Yue, "Computer multimedia assisted English vocabulary teaching courseware," Int. J. Emerg. Technol. Learn., vol. 12, no. 12, pp. 67-78, 2017, doi: 10.3991/ijet.v12.i12.7955.

[28] H. Shamir, E. H. Yoder, D. B. Pocklington, and K. C. Feehan, "Computer-assisted instruction: Long-term effects on early literacy skills of low socioeconomic status students," Int. J. Inf. Educ. Technol., vol. 9, no. 4, pp. 263-267, 2019, doi: 10.18178/ijiet.2019.9.4.1210.

[29] T. Gayatri, H. Soegiyanto, and P. Rintayati, "Development of contextual teaching learning-based audio visual Adobe Flash Media to improve critical thinking ability of geography learning at senior high school," IOP Conf. Ser. Earth Environ. Sci., vol. 145, pp. 1-9, Apr. 2018, doi: 10.1088/1755-1315/145/1/012004.

[30] V. Motamedi, "The promises of presentational technology for teaching and learning," Journal of Education and Learning (EduLearn), vol. 13, no. 3, pp. 416-419, 2019, doi: 10.11591/edulearn.v13i3.13175.

[31] O. A. Ige, "Impact of computer-assisted instructional strategy on school children's social skills," J. Soc. Stud. Educ. Res., vol. 10, no. 4, pp. 490-505, 2019.

[32] P. Ponimin and H. Suryani, "Instructional Media and English: Using Macromedia Flash to Teach EFL Writing," Edukasi J. Pendidik. dan Pengajaran, vol. 6, no. 2, pp. 311-319, 2019, doi: 10.19109/ejpp.v6i2.3971

[33] A. A. Ziden and R. M. F. Abdul, "The effectiveness of web-based multimedia applications simulation in teaching and learning," Int. J. Instr., vol. 6, no. 2, pp. 211-222, 2013.

[34] H. Sarac and D. Tarhan, "Effect of Multimedia Assisted 7e Learning Model Applications on Academic Achievement and Retention in Students," Eur. J. Educ. Res., vol. 6, no. 3, pp. 299-311, Jul. 2017, doi: 10.12973/eu-jer.6.3.299.

[35] R. E. Mayer, "Using multimedia for e-learning," J. Comput. Assist. Learn., vol. 33, no. 5, pp. 403-423, Oct. 2017, doi: $10.1111 /$ jcal.12197.

[36] D. Maresch, R. Harms, N. Kailer, and B. Wimmer-Wurm, "The impact of entrepreneurship education on the entrepreneurial intention of students in science and engineering versus business studies university programs," Technol. Forecast. Soc. Change, vol. 104, pp. 172-179, Mar. 2016, doi: 10.1016/j.techfore.2015.11.006.

[37] V. Fardila, S. Subekti, and T. Setiawati, "The benefits of learning "craft and entrepreneurship" in the growth of entrepreneurship attitudes of students of SMAN 1 Cimahi," (in Indonesia), Media Pendidikan, Gizi, dan Kuliner, vol. 4, no. 2, pp. 66-78, 2015. [Online]. Available: https://ejournal.upi.edu/index.php/Boga/article/view/8421.

[38] J. Alvarez-Cedillo, M. Aguilar-Fernandez, R. J. Sandoval-Gomez, and T. Alvarez-Sanchez, "Actions to be taken in Mexico towards education 4.0 and society 5.0," International Journal of Evaluation and Research in Education (IJERE), vol. 8, no. 4, pp. 693-698, 2019, doi: 10.11591/ijere.v8i4.20278. 
[39] J. Winardi, Entrepreneur dan Entrepreneurship. Jakarta: Prenada Media, 2003.

[40] I. G. Suasana, N. W. Ekawati, I. K. Sudiana, and I. G. Wardana, "Impact of Entrepreneurship Education on Entrepreneur Behavior Index (EBI) and Entrepreneurial Intentions," (in Indonesia), Matrik J. Manajemen, Strateg. Bisnis Dan Kewirausahaan, vol. 14, no. 1, pp. 31-42, 2020, doi: 10.24843/MATRIK:JMBK.2020.v14.i01.p04.

[41] C. Purbaningrum and S. Soenarto, "The development of learning model for crafts and entrepreneurship with principle of the great young entrepreneur in vocational schools for curriculum of 2013," (in Indonesia), J. Pendidik. Vokasi, vol. 6, no. 1, pp. 15-23, 2016, doi: 10.21831/jpv.v6i1.8112.

[42] S. Sukardi, "Model design of prakarya and entrepreneurship with creative economy based and local quality of industry dimension," J. Cakrawala Pendidik., vol. 1, no. 1, pp. 114-124, 2016, doi: 10.21831/cp.v1i1.8381.

[43] B. Sukaharta, N. Santiyadnya, and G. Nurhayata, "Evaluation study of prakarya and entrepreneurship learning process in XII MIPA at SMA Negeri 1 Singaraja," (in Indonesia), J. Pendidik. Tek. Elektro Undiksha, vol. 6, no. 2, pp. 57-65, 2017, doi: 10.23887/jjpte.v6i2.20231.

[44] L. F. Wati, "Project-based learning model based on local potential in craft and entrepreneurship subjects (SMA/SMK in Malang)," (in Indonesia), J. Teor. dan Praksis Pembelajaran IPS, vol. 3, no. 1, pp. 39-47, 2018, doi: 10.17977/um022v3i12018p039.

[45] Sugiyono, Qualitative, qualitative and $R \& D$ research methods, (in Indonesia). Bandung: Alfabeta, 2018.

[46] I. Nasrulloh and A. Ismail, "ICT-based learning needs analysis," (in Indonesia), J. Pendidikan Teknol. Inf. dan Komun., vol. 3, no. 1, pp. 28-32, 2018, doi: 10.31980/jpetik.v3i1.355.

[47] M. Hanif, A. Asrowi, and S. Sunardi, "Students' access to and perception of using mobile technologies in the classroom: the potential and challenges of implementing mobile learning," Journal of Education and Learning (EduLearn), vol. 12, no. 4, pp. 644-650, 2018, doi: 10.11591/edulearn.v12i4.8398.

[48] M. Muhali, "21st century innovative learning," (in Indonesia), J. Res. Educ. Studi. e-Saintika, vol. 3, no. 2, pp. 25-50, 2019, doi: 10.36312/e-saintika.v3i2.126.

[49] N. D. S. Chetty, L. Handayani, N. A. Sahabudin, Z. Ali, N. Hamzah, and S. Kasim, "Learning styles and teaching styles determine students' academic performances," International Journal of Evaluation and Research in Education (IJERE), vol. 8, no. 4, pp. 610-615, 2019, doi: 10.11591/ijere.v8i4.20345.

[50] Z. Notanubun, "The development of teacher professionalism competence in the digital era (21st Century)," (in Indonesia), J. Bimbing. dan Konseling Terap., vol. 3, no. 2, pp. 54-64, 2019, doi: 10.30598/jbkt.v3i2.1058.

[51] S. Suryanti and L. Wijayanti, "Digital literacy: Urgent competence of educators in the era of the industrial revolution 4.0," (in Indonesia), Jurnal Pendidikan Dasar, vol. 2, no. 1, pp. 1-9, 2018. [Online]. Available: https://journal.unesa.ac.id/index.php/jpd/article/view/6259.

[52] D. I. Sari, T. Rejekiningsih, and M. Muchtarom, "Students' digital ethics profile in the era of disruption: An overview from the internet use at risk in Surakarta City, Indonesia," Int. J. Interact. Mob. Technol., vol. 14, no. 03, pp. 82-94, 2020, doi: 10.3991/ijim.v14i03.12207.

[53] S. Malik and A. Agarwal, "Use of multimedia as a new educational technology tool-a study," Int. J. Inf. Educ. Technol., vol. 2, no. 5, pp. 468-471, 2012, doi: 10.7763/ijiet.2012.v2.181.

[54] H. S. Mahdi, "Using multimedia-assisted LINCS for learning English pronunciation," Int. J. Emerg. Technol. Learn., vol. 14, no. 09, pp. 105-117, 2019, doi: 10.3991/ijet.v14i09.10356.

[55] A. A. Kareem, "The use of multimedia in teaching biology and its impact on students' learning outcomes," Eurasia Proc. Educ. Soc. Sci., vol. 9, no. 1, pp. 157-165, 2018.

[56] P. Budiastuti, M. Khairuddin, and M. N. Azman, "E-instructional multimedia in basic concepts of electrical and electronic lessons," J. Technol. Vocation. Educ., vol. 24, no. 2, pp. 262-269, 2018, doi: 10.21831/jptk.v24i2.18714.

[57] C.-C. Kao and Y.-J. Luo, "Effects of multimedia-assisted learning on learning behaviors and student knowledge in physical education lessons: Using basketball game recording as an example," Int. J. Emerg. Technol. Learn., vol. 15, no. 01, pp. 119-139, 2020, doi: 10.3991/ijet.v15i01.11393.

[58] S. R. Manurung and D. D. Panggabean, "Improving students' thinking ability in physics using interactive multimedia based problem solving," J. Cakrawala Pendidik., vol. 39, no. 2, pp. 460-470, 2020, doi: 10.21831/cp.v39i2.28205.

[59] M. A. Lindner, A. Eitel, B. Strobel, and O. Köller, "Identifying processes underlying the multimedia effect in testing: An eye-movement analysis," Learn. Instr., vol. 47, pp. 91-102, 2017.

[60] K. De Witte, C. Haelermans, and N. Rogge, "The effectiveness of a computer-assisted math learning program," $J$. Comput. Assist. Learn., vol. 31, no. 4, pp. 314-329, 2015, doi: 10.1111/jcal.12090.

[61] S. Ruth Iwanger, "Effect of Multimedia Instructional Approach on Mid Basic Ii Pupils' Interest and Retention in Basic Science," Int. J. Sci. Res. Publ., vol. 8, no. 11, pp. 343-384, 2018, doi: 10.29322/ijsrp.8.11.2018.p8339.

[62] A. S. Hapsari, M. Hanif, Gunarhadi, and Roemintoyo, "Motion graphic animation videos to improve the learning outcomes of elementary school students," Eur. J. Educ. Res., vol. 8, no. 4, pp. 1245-1255, Oct. 2019, doi: 10.12973/eu-jer.8.4.1245.

[63] A. Anisa, "Improving students' critical thinking skill through science teaching based on Jepara's local potential," (in Indonesia), J. Inov. Pendidik. IPA, vol. 3, no. 1, pp. 1-11, Apr. 2017, doi: 10.21831/jipi.v3i1.8607.

[64] R. U. Sari, R. Rusdarti, and R. Syamwil, "Development of local potential-based entrepreneurship learning model in vocational schools in West Kalimantan Region," (in Indonesia), J. Vocat. Career Educ., vol. 2, no. 2, pp. 87-95, 2017, doi: 10.15294/jvce.v2i2.13858. 